\title{
Factors Affecting Chicken Livestock Business Income in Lubuk Linggau City
}

\author{
Dita Melandari ${ }^{1)}$, Aris Munandar ${ }^{2)}$, Vhika Meiriasari ${ }^{3)}$ \\ 1), 2), 3) Universitas Indo Global Mandiri, Palembang, Indonesia
}

Email:melandaridita68@gmail.com ${ }^{l),}$ arismunandar@uigm.ac.id ${ }^{2), v h i k a m s @ u i g m . a c . i d ~}{ }^{3)}$

\begin{abstract}
This research aims to analyze the amount of independent chicken business income and the factors that affect the income of independent chicken farming. This study analyzed 5 independent chicken breeders in Lubuk Linggau City which is a chicken production center. The data was collected by the survey method and analyzed using multiple linear regression. The findings of this research identified that the amount of chicken ownership, education, labor, production costs, and selling price had a positive effect on the income of independent chicken breeders in Lubuk Linggau City. While farmers' age and experience did not have a positive effect on their income. The results show the correlation coefficient test $(\mathrm{R})$ obtained a value of 0.82 , which means the relationship between independent variables and income is $82.1 \%$ and the rest is influenced by other variables not included in this study. This research is useful for independent chicken breeders to consider the amount of chicken ownership, education, labor, production costs, and selling price because they have a positive effect on income.
\end{abstract}

Keywords: independent chicken breeders, business income

\section{Introduction}

The livestock sub-sector is part of the agricultural sector which has an important role in supporting the regional and national economy. Poultry business in Indonesia has become a business that has complete components from upstream to downstream sectors. The livestock sub-sector contributed 1.57\% to Indonesia's GDP in 2017 (Directorate General of PKH, 2018). The development of livestock business makes a real contribution to agricultural development and has strategic value, namely meeting the domestic animal protein needs and providing job opportunities for the community.

However, in its development, broiler chicken farms generally face problems, including low capital control, lack of technology mastery, fluctuating prices, low access to markets, and low operating margins. Chicken breeders can collaborate or partner with a company to overcome these problems.

The chicken business in Indonesia has become an industry for business development at this time, the broiler farm business is one type of business that has the potential to be developed. This cannot be separated from various advantages

that are owned by broiler chickens, among others, a relatively short production period of approximately 32-35 days, relatively cheap prices, increasing demand and various other advantages compared to other poultry.

Cost accounting holds three main functions, namely setting the cost of production (product cost), controlling costs (cost control) and making special decisions (special decision making). In this study, the researcher will only discuss one of the objectives of cost accounting, namely calculating the cost of production. To assess the cost of a product, cost accounting records, 
categorizes and summarizes the costs to make a product or service with a certain step.

The success of a livestock business is not only determined by the large number of livestock that are kept, but also must be supported by a good management system, so that production and revenue results are as expected. Part of the revenue is used to cover production costs and the rest is used as income. The size of the income obtained can be used as a measure of the success of managing a business. Income analysis in the beef cattle business needs to be done because so far farmers have not paid attention to the aspects of the financing that have been issued and the income obtained, so that in turn it is not widely known the level of income earned. . This income analysis is needed to determine the amount of production costs and their effect on the income received by farmers (Halim et., al 2014).

\subsection{Problem Formulation}

Based on the background of the problem above, the researchers identified the following problems:

1. Does the cost of production affect the income of independent chicken farms?

2. Does the selling price affect the income of independent chicken farms?,

3. Do production costs and selling prices affect the income of independent chickens?

\subsection{Research Objectives}

Based on the above background, the objectives of this research are:

1. To determine the effect of production costs on income results in independent chicken farms.

2. To determine the effect of selling price per kilogram $(\mathrm{kg})$ on the income of independent chickens.

3. To determine the effect of production costs and income per kilogram on the income of independent chickens.

\section{Literature Review}

\subsection{Production Cost}

According to Supriyono (2018: 19), "Production costs are all costs related to the production function or activities of processing raw materials into finished products." According to Badriyah (2015:45-46), production costs can be grouped into:

\section{Raw Material Cost}

According to Wijaya (2018: 144), "The cost of raw materials is the cost of materials used to be processed and will become materials for finished products. Raw materials are the largest part that make up the finished product so they are classified directly in the cost of each type of goods." According to Putra (2018:119-120), the cost of raw materials can be divided into two types, namely:

a. Direct material cost

Direct material costs are costs that are used to purchase direct materials.

b. Indirect raw material costs

Indirect raw material costs are costs used to purchase indirect raw materials.

\section{Labor Cost}

According to Supriyono (2018:20), labor costs are all remuneration (tekenprestasi) provided by 
the company to all employees. Labor costs in factories are classified into direct labor costs and indirect labor costs.

a. Direct labor costs are remuneration provided to employees whose benefits can be identified or traced to certain products produced by the company.

b. Indirect labor costs are remuneration provided to employees, but the benefits cannot be identified or traced to certain products produced by the company.

\section{Factory Overhead Cost}

According to Sumarsan (2013: 106), "Factory overhead costs are indirect material costs, direct labor costs and all other manufacturing costs that cannot be charged directly to certain products." Production costs included in factory overhead costs are grouped according to their nature as follows. :

1. The cost of auxiliary materials are materials that are not part of the finished product or materials which, although they are part of the product, are relatively small in value when compared to the cost of production.

2. Indirect labor costs are factory workers whose wages cannot be calculated directly for certain products or orders.

3. The cost of electricity is the cost used in the production process to turn on the production machine and as lighting during the production process.

\subsection{Selling Price}

The selling price is a number of costs incurred by a company or organization to produce a product or service plus the percentage of profit desired by the company. The selling price can be determined from the total costs incurred in the production process added to the margin. The selling price according to Achmad is the estimated exchange rate of the product which is determined in money. The selling price is the price obtained from the sum of the total production costs plus the mark-up used to cover the company's factory overhead costs.

According to Gregory Lewis, as quoted by Achmad, the selling price is the amount of money the buyer is willing to pay and the seller is willing to accept. The selling price is the value reflected in the list price, the retail price, and the price is the final value received by the company as revenue or net price. The selling price is the sum of the cost of goods sold, administrative costs, selling costs, and the desired profit.

\subsection{Income}

Income is the profit of farming in one year's business which is for the owner, wages, management and own capital used for the business (Ratnasari, et al., 2015). Every farmer always expects success in his business. The ability of farmers to manage their business is a very decisive factor in achieving optimal results in laying hens. The size of the business scale does not guarantee that the productivity obtained by farmers will be high if it is not supported by good maintenance management in running their livestock business (Andri et al., 2011). Basically, the goal of every business is to get the maximum profit possible and to be able to maintain the sustainability of its business. A livestock business is said to be financially feasible if the profits obtained are greater than the costs incurred so that the business can survive (Amrizal, et al., 2011).

Factors that affect revenue are product sales volume and product selling price. In general, the main goal to be achieved by a company is to earn revenue. Sales volume is a very important 
factor affecting the size of the income that will be obtained by farmers for their efforts in carrying out broiler type maintenance. To get the maximum profit from sales, farmers must keep their livestock deaths as low as possible. Then for the selling price of the product, it is a value in the form of money to appreciate every product produced from a business, such as a broiler farming business whose products are live chickens which are rewarded with an amount of money per kilogram (Suwiangadana, et al., 2013).

\subsection{Framework}

The research conceptual framework explains the relationship between the variables to be tested, namely the analysis of the factors that influence the income of independent chickens in the city of Lubuklinggau. The framework of the research concept can be seen in this figure:

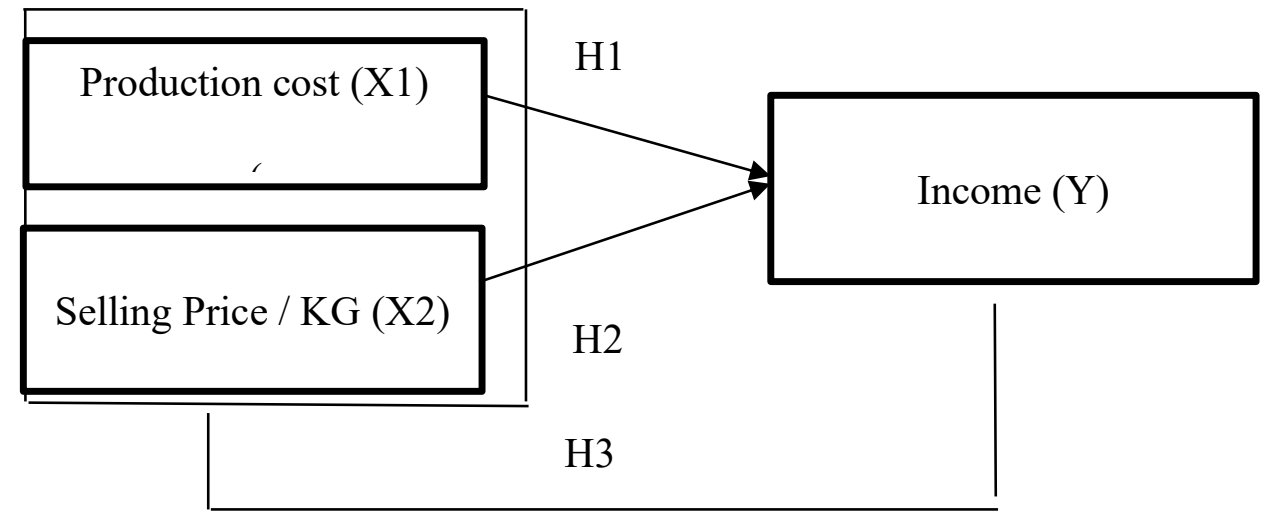

Figure 1: Framework

\subsection{Hypothesis}

H1 : Production costs have a significant effect on the income of independent chickens in Lubuk Linggau City

H2 : Selling price has a significant effect on the income of independent chickens in Lubuk Linggau City.

H3 : Production Costs, Selling Prices have a significant effect on the income of independent chickens in Lubuk Linggau City

\section{Research Method}

The study used a survey method by going through two stages, namely the pre-survey stage and the survey stage. The pre-survey stage is carried out to determine the research location and the breeders who will be respondents. The survey stage was carried out to collect data through direct interviews with respondents based on a list of existing questions and to see firsthand the condition of farmers

\subsection{Population and sample}

Population is a number of objects/subjects in a study that have certain characteristics and qualities. The population in this study were all chicken farmers in Lubuk-Linggau City.

The farmer sampling method is selected by farmers in the sample group who have independent 
chicken farmers in the production period and have been in maintenance for five years.

\subsection{Technical Analysis}

Technical analysis of the data used in this study is to use the SPSS statistical tool in performing the Classical Assumption Test Hypothesis Testing, t-test, F-test, and the Coefficient of Determination (R2).

\subsection{Variable Operational Definition}

\section{Production costs}

Production costs are costs related to the calculation of the cost of production or cost of goods sold.

2. Selling Price Variable

Selling price is the amount of price charged / charged to consumers obtained from the calculation of production costs plus non-production costs and the expected profit.

3. Income variable

Income is the amount of money received by the company from its activities, mostly from selling products and services to customers.

\section{Findings and Discussions}

Based on the results of the classical assumption test, the research model meets the classical assumption test. then, after the classical assumption test is met, the next step is to test the hypothesis. The following are the results of hypothesis testing which include $t$ and $F$ test .

Tabel 1. t- Test Results

\begin{tabular}{|c|c|c|c|}
\hline \multicolumn{4}{|c|}{ Coefficients $^{\mathrm{a}}$} \\
\hline Mo & & $\mathrm{T}$ & Sig. \\
\hline \multirow[t]{3}{*}{1} & (Constant) & -3.303 & .003 \\
\hline & $\begin{array}{l}\text { Production } \\
\text { Cost }\end{array}$ & 3.235 & .004 \\
\hline & Selling Price & 1.733 & .097 \\
\hline
\end{tabular}

a. Dependent Variable: income

Source: Data processed by researchers

Based on the results of the calculations in table 4.5 , the variable production costs have a significant positive effect on the income of the chicken farming business with a significance of 0.004 which is smaller than a significance level of 0.05 . Thus the hypothesis $\left(\mathrm{H}_{1}\right)$ which states the effect of production costs on income is accepted.

Based on the results of the calculations in table 4.5, it can be concluded that the selling price variable has no significant effect on the income of independent chickens in Lubuk Linggau City. The variable selling price of chickens in Lubuk Linggau city with a significance value of 0.097 is greater than a significance level of 0.05 . Thus, the hypothesis (H2) which states that there is an effect of selling price on income is rejected. 
Tabel 2. F-Test Results

\begin{tabular}{|c|c|c|c|c|c|c|}
\hline \multicolumn{7}{|c|}{ ANOVA $^{a}$} \\
\hline \multicolumn{2}{|c|}{ Model } & Sum of Squares & $\mathrm{df}$ & Mean Square & $\mathrm{F}$ & Sig. \\
\hline 1 & Regression & $\begin{array}{r}6229864391199056.0 \\
00\end{array}$ & 2 & $\begin{array}{r}3114932195599528.0 \\
00\end{array}$ & 50.369 & $\begin{array}{r}.000 \\
\mathrm{~b}\end{array}$ \\
\hline & Residual & $\begin{array}{r}1360529614800943.8 \\
00\end{array}$ & 22 & 61842255218224.720 & & \\
\hline & Total & $\begin{array}{r}7590394006000000.0 \\
00\end{array}$ & 24 & & & \\
\hline
\end{tabular}

a. Dependent Variable: income

b. Predictors: (Constant), selling price, production cost

Source: Data processed by researchers

In Table 2, the Fcount value is 50.369 and the sig value is 0.000 where the Ftable value for 3 samples with a probability of 0.05 is 3.028 so it can be concluded that $50.369>3.028$, then sig $0.000<0.05$ then the result rejects $\mathrm{H} 0$ and accepts Ha or In other words, the variables of production costs and selling prices simultaneously (simultaneously) affect the income variable of independent chicken farms in Lubuk Linggau City, although with different contributions, with these results, the second hypothesis proposed by the researcher is proven.

Based on the calculation of the F test that has been carried out, it can be concluded that all of the independent variables (production costs and selling prices) have a significant simultaneous or joint effect on the dependent variable (income), thus chicken owners should consider the production cost variable properly. and the selling price before making a decision to raise chickens in Lubuk Linggau city, because these variables quite affect the income in chicken farming.

\section{References}

Amam, A., Fanani, Z., Hartono, B., \& Nugroho, B. A. (2019). Usaha Ternak Ayam Pedaging Sistem Kemitraan Pola Dagang Umum: Pemetaan Sumber Daya dan Model Pengembangan. Sains Peternakan, 17(2),

Crisdandi, P. (2015). Pengaruh Biaya Pemeliharaan dan Harga Jual Terhadap Pendapatan Petani Cengkeh Di Desa Tirta Sari Pada Tahun 2014. Jurnal Jurusan Pendidikan Ekonomi (JJPE), 5(1), 1-11.

Dirgantoro. Muh. Arief. dkk. (2019). Implementasi Dan Faktor-Faktor Ya Memengaruhi Perternakan Dalam Memilih Berusaha Ternak AyamBroilerMelalui Pola Kemitraan Inti Plasma Di kota Kendiri. Matahari Program Magister Agribisnis Universitas HaluOleo. Staf Pengajar Program MagisterAgribisnis Univer sitas Halu Oleo

Faisol, M. A., Ermawati, E., Daniar, W., \& Lumajang, S. W. (2019). Analisis Perhitungan Harga Pokok Produksi Sebagai Dasar Untuk Menentukan Harga Jual Pada Cv Arlins Batik Tempeh Kidul. 29-34.

Ilham, F., Laya, N. K., Daud, D., \& Nursali, F. (2019). JU-ke ( Jurnal Ketahanan Pangan ), 3(2), 
$8-14$.

Loing, J. C., \& Makalew, A. (2016). Analisis finansial usaha ternak ayam kampung di kecamatan kawangkoan kawasan agropolitan kabupaten minahasa. 3, 51-56.

Lestari, F. W. (2016). Sistem Pakar Penentuan Jenis Penyakir Ayam dengan Metode Forward Chaining Berbasis Android. Journal of Chemical Information and Modeling, 53(9), 93103.

Majalengka, K., \& Maja, K. (2015). Pedaging di Kabupaten Majalengka Lili Adam Yuliandri Dosen Program Studi Peternakan Fakultas Pertanian, Universitas Majalengka, Email : adam_tea@yahoo.com.3(1995),10-14.

Nugroho, B.A. dkk. (2019). Usaha Ayam Pedaging Siste Kemitraan Pola Umum:Pemetaan Sumber Daya Dan Modal Pengembangan. Fakultas Perternakan Universitas Brawijaya 65145

Ningsih, N. A. Y. U. (2020). Ayam Broiler Bermitra.

Pradita, D., Sarengat, W., \& Handayani, M. (2015). Efisiensi Produksi Peternakan Ayam Pedaging Riski Jaya Abadi kebumen Ditinjau dari Efisiensi Manajemen, Teknis dan Ekonomis. Animal Agriculture Journal, 4(April), 75-80.

Pedaging, A. R., \& Belakang, L. (2015). Analisis Pendapatan Usaha Ternak Ayam Ras Pedaging Pada Pola Usaha Yang Berbeda Di Kecamatan Cingambul Kabupaten Majalengka Ulfa Indah Laela Rahmah Dosen Program Studi Peternakan Fakultas Pertanian Universitas Majalengka Email: Email: ulfai927@gmail.com seluruh Indonesia. 3, 1-15.

Peternakan, J., Pertanian, F., \& Bengkulu, U. (n.d.). Analisis Faktor-Faktor Pengelolaan Manajemen 50 Kota Provinsi Sumatera Barat (Analysis of Layers Farming Management Factors In District Of 50 Kota West Sumatera Province) Yosi Fenita. 10(2), 225-241.

Pacitan, K. (2012). Analisis Pendapatan Usaha Peternakan Ayam Buras (Studi Kasus di Kecamatan Tegalombo, Kabupaten Pacitan). 36(1), 48-56.

Pradita, D., Sarengat, W., \& Handayani, M. (2015). Efisiensi Produksi Peternakan Ayam Pedaging Riski Jaya Abadi kebumen Ditinjau dari Efisiensi Manajemen, Teknis dan Ekonomis. Animal Agriculture Journal, 4(April), 75-80.

Rahmawati, I. R., Muksin, M., \& Rizal, R. (2016). Peran dan Kinerja Penyuluh Pertanian dalam Memberdayakan Peternak Ayam Petelur di Kabupaten Jember, Provinsi Jawa Timur. Jurnal Penyuluhan, 12(2), 183. https://doi.org/10.25015/penyuluhan.v12i2.12252

Rahmah, Ulfa Indah Laela. (2015). Analisis Pendapatan Usaha Ternak Ayam RasPedaging Pada Pola Usaha Yang Berbeda Di Kecamatan CingambulKabupaten Majalengka. Dosen Program Studi Peternakan Fakultas Pertanian Majalengka.

Retnani, E. B., \& Satrija, F. (2009). Analisis Faktor-Faktor Resiko Infeksi Cacing Pita pada Ayam Ras Petelur Komersial di Bogor. Jurnal Veteriner, 10(3), 165-172..

Rudiawan, M., Bahari, B., \& Dirgantoro, M. A. (2019). Implementasi Dan Faktor-Faktor Yang Memengaruhi Peternak Dalam Memilih Berusaha Ternak Ayam Broiler Melalui Pola Kemitraan Inti Plasma Di Kota Kendari. Jurnal Sosio Agribisnis, 4(1), 12-19. https://doi.org/10.33772/jsa.v4i1.7416

Ratnasari, R., Sarengat, W., \& Setiadi, A. (2015). Analisis pendapatan peternak ayam broiler pada sistem kemitraan di Kecamatan Gunung Pati Kota Semarang. Animal Agricultur Journal, 4(1), 47-53.

Suryanti, R. (2020). Keberlanjutan Usaha Peternakan Ayam Ras Pedaging Pada Pola Kemitraan Sustainability Of Broiler Farming On Partnership Pattern. Jurnal Pangan, 28(3). https://doi.org/10.33964/jp.v28i3.446 
Sudrajat, S., \& Yuniawan Isyanto, A. (2018). Faktor-Faktor Yang Berpengaruh Terhadap Pendapatan Usaha Ternak Ayam Sentul Di Kabupaten Ciamis . Mimbar Agribisnis: Jurnal Pemikiran Masyarakat Ilmiah Berwawasan Agribisnis, 4(1), 70-83.

Stigma, A., \& Barat, R. (2018). Laporan Akhir Tahun Penelitian Disertasi Doktor, 1-105.

Sumarsih, S., \& Mukminan, M. (2016). Pengembangan Multimedia Akuntansi Biaya Metode Harga Pokok Pesanan Bagi Mahasiswa Jurusan Pendidikan Akuntansi Uny. Jurnal Inovasi Teknologi Pendidikan, 3(1), 92.

Wardoyo, D. U. (2016). Analisis Perhitungan Harga Pokok Produksi Dan Penentuan Harga Jual Atas Produk (Studi Kasus Pada PT Dasa Windu Agung). Jurnal Riset Manajemen Dan Bisnis (JRMB) Fakultas Ekonomi UNIAT, 1(2), 183-190. https://doi.org/10.36226/jrmb.v1i2.23

Wardoyo, D. U. (2016). Analisis Perhitungan Harga Pokok Produksi Dan Penentuan Harga Jual Atas Produk (Studi Kasus Pada PT Dasa Windu Agung). Jurnal Riset Manajemen Dan Bisnis (JRMB) Fakultas Ekonomi UNIAT, 1(2), 183-190. https://doi.org/10.36226/jrmb.v1i2.23 